\title{
Synthesis of Zeolite X from Locally Sourced Kaolin Clay from Kono-Boue and Chokocho, Rivers State, Nigeria
}

\author{
Victor Peter Maciver ${ }^{1}$, Kenneth K. Dagde ${ }^{1 *}$, Joshua Lelesi Konne ${ }^{2}$ \\ ${ }^{1}$ Department of Chemical/Petrochemical Engineering, Rivers State University, Nkpolu-Oroworukwo, Port Harcourt, Nigeria \\ ${ }^{2}$ Department of Chemistry, Materials Chemistry Unit, Rivers State University, Nkpolu-Oroworukwo, Port Harcourt, Nigeria \\ Email: *dagde.kenneth@ust.edu.ng
}

How to cite this paper: Maciver, V.P., Dagde, K.K. and Konne, J.L. (2020) Synthesis of Zeolite X from Locally Sourced Kaolin Clay from Kono-Boue and Chokocho, Rivers State, Nigeria. Advances in Chemical Engineering and Science, 10, 399-407. https://doi.org/10.4236/aces.2020.104025

Received: May 5, 2020

Accepted: October 19, 2020

Published: October 22, 2020

Copyright $\odot 2020$ by author(s) and Scientific Research Publishing Inc. This work is licensed under the Creative Commons Attribution International License (CC BY 4.0).

http://creativecommons.org/licenses/by/4.0/

\section{(c) (i) Open Access}

\begin{abstract}
This work describes the development of a process to produce zeolite $\mathrm{X}$ from mined kaolin clay from Kono-Boue and Chokocho, Rivers State, Nigeria. The procedures involved the beneficiation of the raw kaolin and calcinations at $850^{\circ} \mathrm{C}$, to transform the kaolin to a more reactive metakaolin. Afterwards, the extremely reactive metakaolin was purge with sulphuric acid to obtain the much needed silica-alumina ratio for zeolite $\mathrm{X}$ synthesis. An alkaline fusion stage was then carried out to transform the metakaolin into zeolite by mixing with aqueous $\mathrm{NaOH}$ to form gel then allowed to stay for a duration of seven days at room temperature. The samples were then charged into a propylene container and placed in an oven at a temperature of $100^{\circ} \mathrm{C}$ for the reaction to take place for $6 \mathrm{~h}$. Identification of the crystalline phases by X-ray Diffraction (XRD), chemical/elemental compositions by X-ray Fluorescence (XRF)/Energy Dispersive Spectroscopic analyses (EDS), surface morphology by Scanning Electron Microscopy (SEM) and molecular vibration of units by Fourier Transform Infrared Spectrophotometry (FT-IR) were done. The results showed that the zeolite synthesized from Chokocho kaolin (CK) was more crystalline/larger with sharper peaks on both XRD and FTIR than that from Kono-Boue. This was also supported by slightly rougher surface morphology of CK over KK on SEM. XRF Si:Al ratios of 10.73 and 14.36 were obtained for KK and CK respectively. EDS results supported the XRF ratios. Sharper zeolitic characteristic O-H stretching bands at 3488 and $3755 \mathrm{~cm}^{-1}$ were recorded for CK than $\mathrm{KK}$. However, both results showed that zeolite $\mathrm{X}$ have been produced from both Kono-Boue and Chokocho kaolin clays respectively.
\end{abstract}

\section{Keywords}

Kaolin, Metakaolin, Dealuminated Metakaolin, Zeolite X, X-Ray Diffraction and Infrared Spectroscopy 


\section{Introduction}

The study focused on the synthesis of zeolite $\mathrm{X}$ from locally sourced clay from Kono-Boue and Chokocho, Rivers State, Nigeria. Nigeria is abundantly blessed with natural reserves of crude oil with three modern petroleum refineries. Two of them possess profit-boosting units called the Fluid Catalytic Cracking (FCC) units responsible for cracking of heavy refining fractions known as the heavy oil into gasoline and other light and economically viable fuels. Like any other modern refinery, the cracking processes in the FCC units rely completely on availability of this indispensable zeolite catalyst which is continuously imported into Nigeria in millions of tonnes; a scenario which leads to huge capital flight [1].

Zeolites belongs to a well-defined class of naturally occurring and synthetically produced, crystalline aluminosilicate minerals which possesses three-dimensional structures arising from oxygen linked framework of $\left[\mathrm{SiO}_{4}\right]^{4-}$ and $\left[\mathrm{AlO}_{4}\right]^{5-}$ polyhedra. They have the ability of being facile and can also undergo reversible cation exchange. The collections of tetrahedral shape possessed by zeolites initiate a porous matrix with regular arrays of openings having well-defined dimensions so as to be able to selectively admit some molecules into their interiors, whilst rejecting others on the basis of molecular dimensions, giving them the important characteristics of "molecular sieving." The ion exchange and molecular sieving properties of zeolites have given room to the successful commercialization of zeolites for industrial scale ammonia treatment and in detergent formulations as calcium sequesterants which makes zeolites a potential catalyst for the removal of strong and heavy metals from acid, mine drainage and industrial wastewaters [2].

Catalysts (zeolites) are essentials for production technology especially in this country (Nigeria). It finds a number of applications in numerous industrial processes such as adsorbents for water purification, catalyst in the petroleum refining industry for the fluid cracking of heavy petroleum fractions, advanced materials preparation, etc. Therefore, the idea of producing synthetic zeolite to continuously replace its limited imported analog cannot be overemphasized.

Nigeria though being blessed with abundant kaolin clay and solid mineral deposits scattered in various parts of the country, yet the country still depends on imported zeolites as commercial adsorbent for waste water treatment, catalyst for petroleum industry and other applications [3].

Against this backdrop, it becomes imperative to consider a cheaper way of producing zeolite using available natural resources such as clay from Rivers State, Nigeria in support of what previous researchers have done. Initial studies on the synthesis of zeolite from locally deposited clay have been reported by [4]-[11] Zeolites are generally synthesized from low priced silica-alumina sources in alkaline phase under hydrothermal conditions [12]. The cheap silica-alumina sources include kaolinite. Zeolites are normally synthesized from kaolinite by a process known as the "hydrogel process" and its formation could be investigated by the presence of a single characteristic broad band associated with $\mathrm{O}-\mathrm{H}$ stretching vibrations of the catalytic centers ( $\mathrm{Si}-\mathrm{OH}-\mathrm{Al}$ sites) located in the region between $3700-3500 \mathrm{~cm}^{-1}$ [13]. It is therefore very pertinent for researchers, engineers, to 
continuously investigate properties that will favour the conversion of kaolin clay to zeolite, considering it's applications in our economy. Hence, in this research work the synthesis of zeolite from locally sourced clay was investigated.

Although, Konne, et al. [9] investigated the characterization of Kono-Boue clay sourced from Ogoni land in Rivers state using Energy Dispersive X-ray (EDX), there is no report on the synthesis of zeolites from the Kono-Boue and Chokocho clay yet. Therefore, this work applied locally sourced clay from these two selected towns in Rivers State, Nigeria to the synthesize zeolites which can possibly be used in FCC units, water treatment, etc.

The project will provide a veritable national hub for the synthesis of zeolitic materials and their applications in the oil and gas industry as well as allied industries in Nigeria. The work will help in capacity building in terms of highly trained and skilled personnel and provision of cutting-edge equipment in Rivers State and Nigeria at large.

\section{Materials and Methods}

\subsection{Sample Collection and Treatment}

Clay samples selected for this work were taken from Kono-Boue town situated on Latitude $4^{\circ} 42^{\prime}$ and Longitude $7^{\circ} 22^{\prime}$ in Khana Local Government Area of Rivers State and from Chokocho town situated on Latitude $4^{\circ} 59^{\prime}$ North and Longitude $7^{\circ} 08^{\prime}$ East of Greenwich meridians in Etche Local Government Area of Rivers State near the Otamiri River in Rivers State. The clay soil was collected manually at a depth of about $40 \mathrm{~cm}$. The clay samples were neatly kept in a white polythene bag to ensure that there was no physical or environmental contamination of the clay sample. The beneficiation of the clay was carried out in a manner similar to that reported by Emofuriefa, et al. [14]. The clay was transformed to a more reactive form by subjecting it to heating at $850^{\circ} \mathrm{C}$ for $6 \mathrm{~h}$ using a furnace before using it as a reactant. This was because the $\mathrm{Si}-\mathrm{O}$ or Al-O tetrahedral and octahedral structures possessed by kaolin are inactive to modification or activation which can hinder the direct synthesis of zeolites. Therefore kaolin must be subjected to thermal transformation to change the inert phase into the active phase at elevated temperature with the addition of an alkali hydroxide. Metakaolin is a reactive phase which characterized the fusion process with the addition of sodium hydroxide to form active $\mathrm{Al}$ and $\mathrm{Si}$ species which have the tendency of forming ring-like structures that are basic unit for zeolite formation.

\subsection{Zeolitization}

The dealumination of $30 \mathrm{~g}$ metakaolin with sulphuric acid leached out the structural alumina to meet the silica-alumina mole ratio required for the targeted zeolite. This is because each $\mathrm{AlO}_{4}$ tetrahedron in zeolite framework bears a net negative charge which is balanced by a cation. The structural formula of zeolite is based on the crystallographic unit cell, represented as 


$$
M_{x / n}\left[\left(\mathrm{AlO}_{2}\right)_{x}\left(\mathrm{SiO}_{2}\right)_{y}\right] \cdot w \mathrm{H}_{2} \mathrm{O}
$$

where $M$ is an alkali or alkaline earth cation, $n$ is the valence of the cation, $w$ is the number of water molecules per unit cell, $x$ and $y$ are the total number of tetrahedra per unit cell, and the ratio $y / x$ usually has values of 1 to 5 while high silica zeolites', $y / x$ can range from 10 to 100 [15].

A gel from the dealuminated metakaolin and a solution of sodium hydroxide was prepared based on the procedure required for the synthesis of faujasite after which the gel formed was left to age for 7 days at room temperature in a propylene container. The gel sample was heated in a microwave oven set at $100^{\circ} \mathrm{C}$ for $6 \mathrm{~h}$. After the synthesis, the samples were filtered, dried, labelled and characterized.

\subsection{Sample Analysis (XRD. XRF, SEM, EDS and FT-IR)}

X-ray diffraction was used to identify the crystalline phase of the samples while the chemical composition was determined with the XRF (Thermo Scientific, Niton Analyzer, Model: XL3t 950) using the $\mathrm{Cu}-\mathrm{Zn}$ method. XRD samples were ground, pressed with a smooth flat spatula surface upon silica wafers and slotted into the sample holder in the diffractometer for analysis. The surface morphology and elemental analysis were jointly analysed using Phenom ProX Desktop Scanning Electron Microscope and Energy dispersive X-ray Spectroscopy (SEM-EDS). Small amount of each sample was placed on a carbon sticky pad attached to aluminium stubs (sample holders) for SEM-EDS analysis.The SEM and EDS provided the surface morphology and elemental analysis of the imaged samples respectively. Molecular vibrations of the Functional units were investigated using the Fourier Transform Infrared (FT-IR) Spectroscopy (Shimadzu Fourier Transform Infrared Spectrophotometer-FT-IR 8400 S). FT-IR samples (0.01 g each) were homogenized with the same quantity of $\mathrm{KBr}$ with agate mortar and pestle. The mixtures were pressed by vacuum hydraulic Press at $1.2 \mathrm{psi}$ into a transparent pellet which was scanned between $400-4000 \mathrm{~cm}^{-1}$.

\section{Results and Discussion}

\subsection{XRD Analysis}

The X-ray diffraction patterns of the crystallized zeolites are shown in Figure 1(a) and Figure 1(b) for zeolites X from the Kono-Boue and Chokocho kaolin, respectively. The reflection patterns showed sharp peaks indicating that both samples were crystalline at this stage. The patterns matched with both synthetic and commercial NaX-zeolite. XRD patterns reported in literature except for weaker intensity of the peak at 2-theta $=6.28^{\circ}$ [12]. It was also similar to the untreated calcined kaolin reported by Konne, et al. [9] indexed to the Joint Committee on Powder Diffraction Standards (JCPDS) file number: 003-0447. The major difference was the higher crystallinity observed for KK and CK zeolites in this report. The sharper peaks and lower broad background on the XRD pattern of CK indicated that it was more crystalline/of larger particle sizes than KK. 


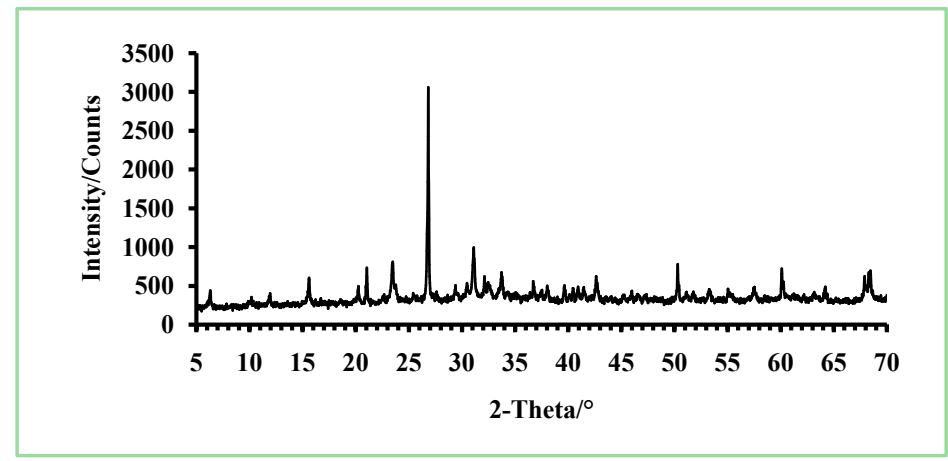

(a)

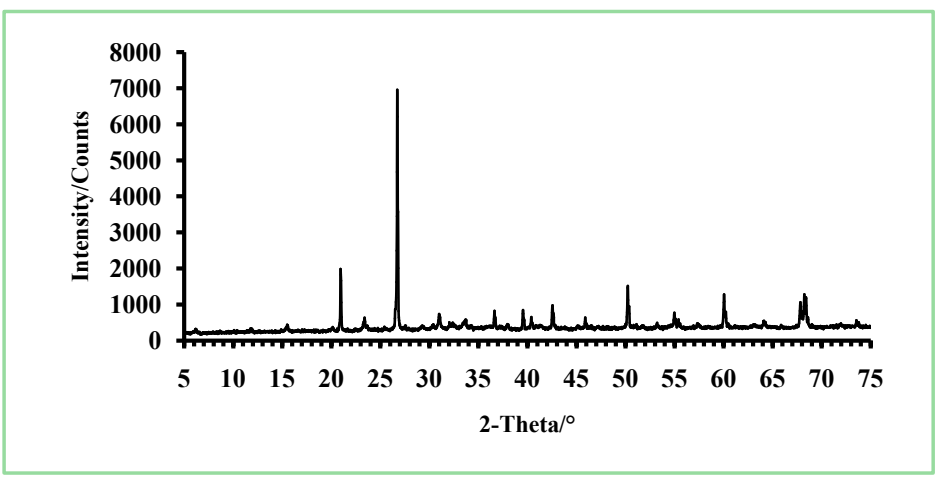

(b)

Figure 1. X-ray diffraction patterns for zeolites from (a) Kono-Boue and (b) Chokocho kaolin measured at room temperature.

\subsection{X-Ray Fluorescence (XRF)}

The XRF data of the treated kaolin samples showed irregular pattern with the treatment processes. There was a general increase in the concentrations of silica and alumina for the calcined kaolin of both samples with comparison to the raw kaolin (Figure 2). The results showed that silica and alumina concentrations in the calcined Kono-Boue kaolin were $25.252 \%$ and $5.310 \%$ while that of the calcined Chokocho kaolin were $27.601 \%$ and $5.624 \%$ respectively. Considerable increase in the concentrations of impurities like $\mathrm{Fe}_{2} \mathrm{O}_{3}$ and $\mathrm{TiO}_{2}$ were also observed. However at the beneficiation stage, there was a drop and rise in silica concentrations for Kono-Boue and Chokocho kaolin, respectively. On the other hand, an overall effect of increase in silica-alumina ratio was noticed in the dealuminated samples of both Kono-Boue kaolin (DKK) and Chokocho kaolin (DCK). This was as a result of removal of the alumina content of the clay using sulphuric acid. The reaction was enhanced by the large surface area achieved under calcinations. The result showed that the beneficiation, calcinations and de-alumination treatments were essential for the enhancement of silica:alumina ratios for the two samples. The XRF data showed the expected high Si:Al ratio range of 10.73 and 14.36 for zeolite $\mathrm{X}$ of $\mathrm{KK}$ and $\mathrm{CK}$ respectively. However, the results showed that better ratio was achieved for both KK and CK after treatments compared to the raw kaolin for KK and CK. 


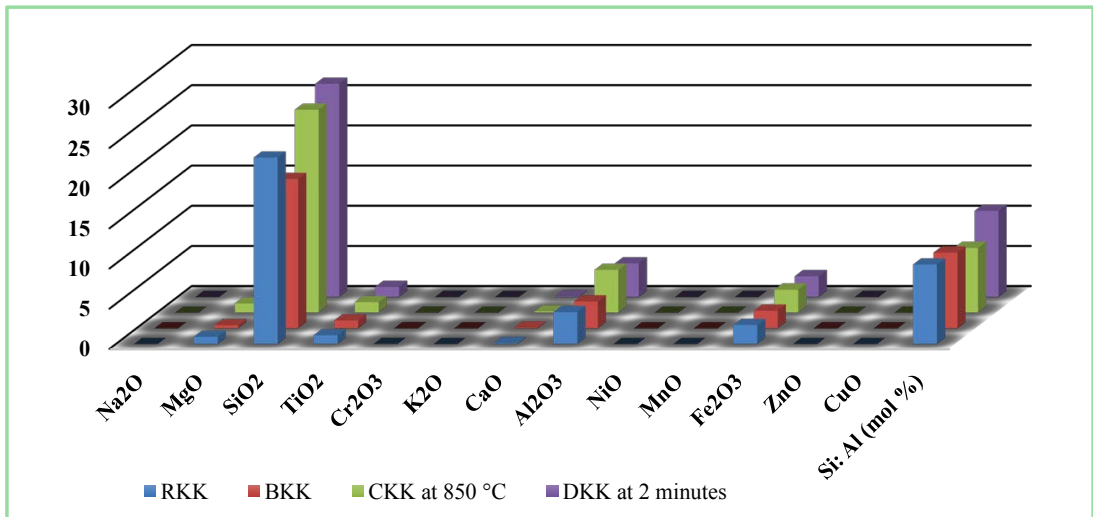

(a)

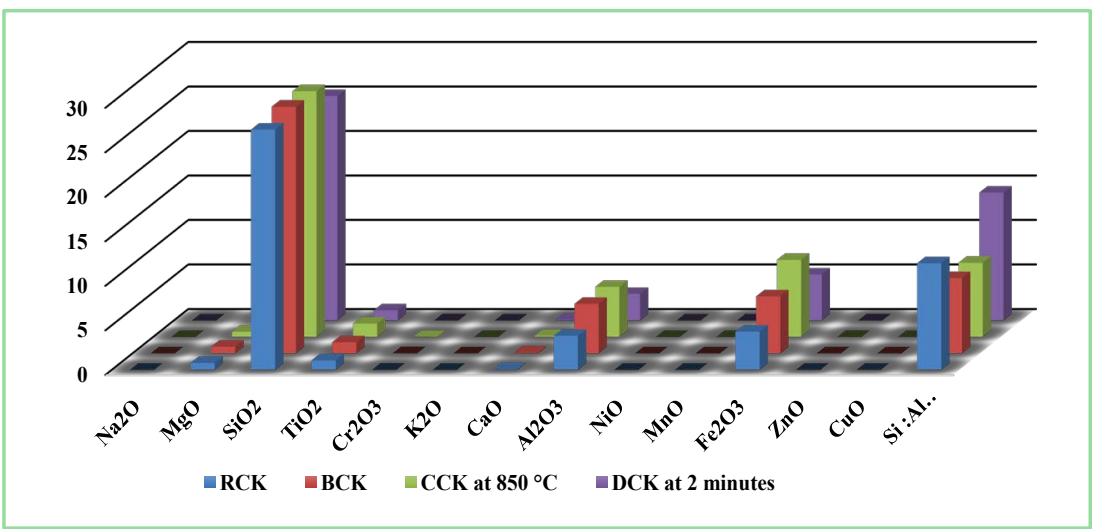

(b)

Figure 2. XRF charts of raw kaolin (RK), beneficiated kaolin (BK), calcined kaolin (CK) and de-aluminated kaolin (DK) kaolin of (a) Kono-Boue and (b) Chokocho samples respectively.

\subsection{SEM and EDS}

The surface morphologies of the synthesized zeolites of both Kono-Boue and Chokocho showed microporous polycrystallites with rough surfaces of largely smaller particles mixed with scattered larger aggregates Figure 3. The larger aggregated polycrystallites were more on the Chokocho micrograph than Kono-Boue confirming the observed differences in crystallinity shown on the XRD. The EDS showed Si:Al ratios from atomic concentrations as 1.36 (besides Figure 3(a)) and 1.51 (besides Figure 3(b)) for KK and CK respectively. The EDS results supported the empirical ratios obtained from the XRF technique. Similarly, the atomic concentrations of $\mathrm{Na}$ were 36.83 and 36.18 for $\mathrm{KK}$ and $\mathrm{CK}$ respectively which indicated that the $\mathrm{Na}^{+}$ions required to balance the net negative charge of $\mathrm{Al}$ tetrahedron varied with $\mathrm{Al}$ concentration in the synthesized NaX-zeolites [15].

Both zeolite samples contained low/trace concentrations of other elements associated with mineralogical impurities found in zeolite $\mathrm{X}$ which is critical for the nucleation, growth or crystallization of the zeolitic phase [16]. The levels of $\mathrm{Fe}, \mathrm{Ag}, \mathrm{K}, \mathrm{Mg}$ and $\mathrm{P}$ in $\mathrm{CK}$ were higher than $\mathrm{KK}$ while $\mathrm{Ti}$, S and $\mathrm{Ca}$ in $\mathrm{KK}$ were higher than those of $\mathrm{CK}$. In addition, only KK had trace concentration of $\mathrm{Zr}$. 


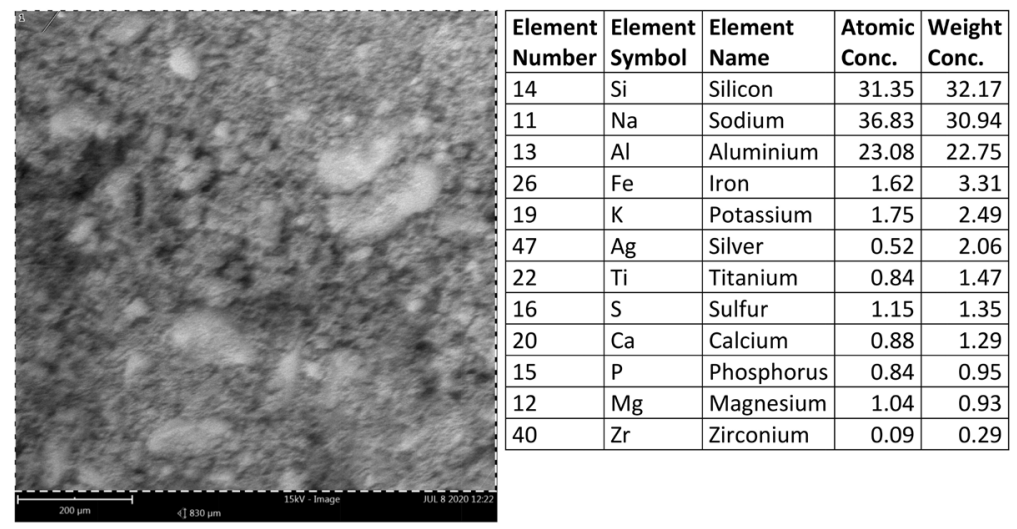

(a)

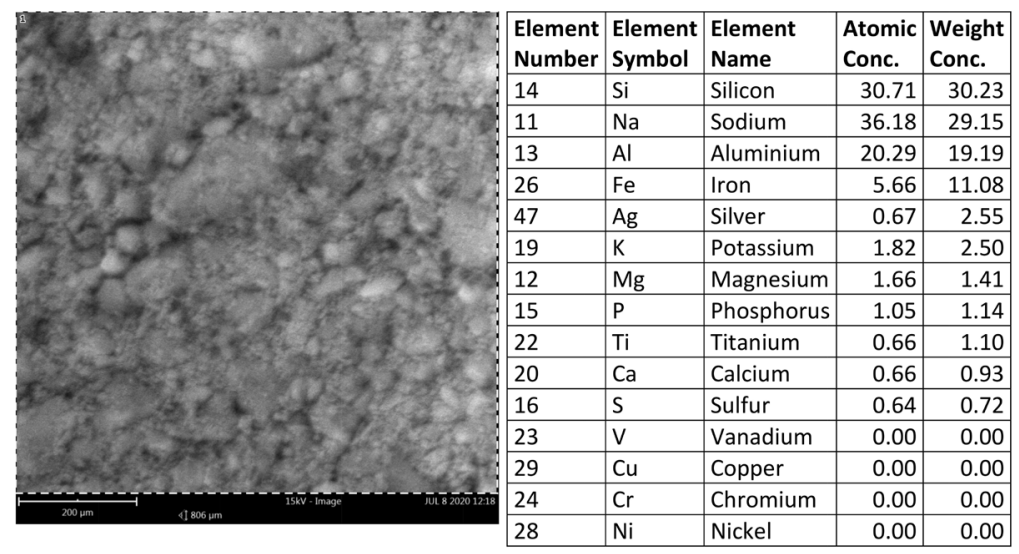

(b)

Figure 3. SEM and EDS of (a) zeolite-X from Kono-Boue and (b) zeolite-X from Chokocho respectively.

The absence of some toxic heavy metals such as $\mathrm{Pb}, \mathrm{Cd}, \mathrm{Cr}$, etc. from both samples implied that the resultant zeolites were safer than some earlier reports in literature [17].

\subsection{FT-IR}

The results of the FT-IR of the two zeolitic products are shown in Figure 4. The lower bands range of $466-857 \mathrm{~cm}^{-1}$ represent bands associated with symmetric stretching vibrations of $\mathrm{Al}-\mathrm{O}$ and $\mathrm{Si}-\mathrm{O}$ units. These bands are clearly seen in the CK sample spectrum but are broader and very weak on the KK sample spectrum below CK. The band at $752 \mathrm{~cm}^{-1}$ has been associated with $\mathrm{Si}-\mathrm{O}-\mathrm{Al}$ in zeolites [18]. This region is followed by a broad band $\left(992 \mathrm{~cm}^{-1}\right)$ assigned to asymmetric stretching vibrations of internal bonds of a tetrahedra [16] [18]. The characteristic bending vibration of a four membered ring (tetrahedra) has been associated with the lowest band at $466 \mathrm{~cm}^{-1}$ in zeolites [17]. The presence of absorbed $\mathrm{CO}_{2}$ and water molecules in the zeolite channels has been associated with bands at $1407-1482$ $\mathrm{cm}^{-1}$ and $1660-1671 \mathrm{~cm}^{-1}$ respectively. This region was followed by a large broad band with weak peaks at $2380 \mathrm{~cm}^{-1}$ that could not be assigned to any known vibration in the available literature while bands at $2936 \mathrm{~cm}^{-1}$ could be due to $\mathrm{H}_{2} \mathrm{O}$ 


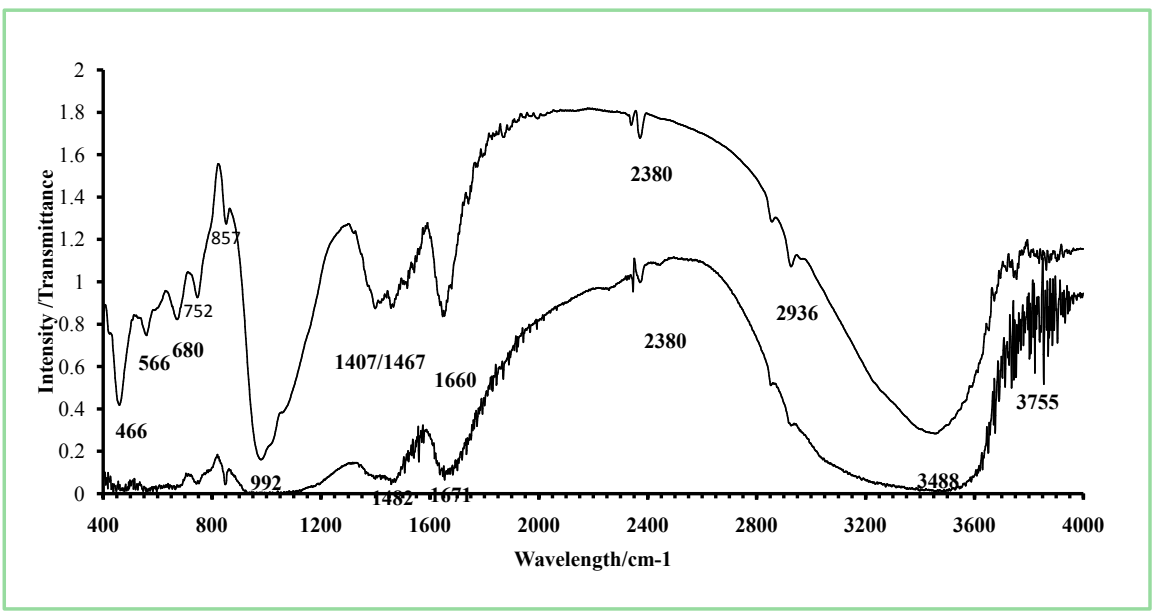

Figure 4. FT-IR Spectrum of synthesized Zeolites X samples from Kono-Boue and Chokocho clay respectively.

stretching. The characteristic broad bands at 3488 and $3755 \mathrm{~cm}^{-1}$ were all assigned to zeolitic $\mathrm{O}-\mathrm{H}$ stretching vibrations which was more intense in $\mathrm{CK}$. The higher intensity of the CK FT-IR bands above the KK agreed with the XRD and SEM of higher crystallinity of CK over KK.

\section{Conclusion}

Zeolite was successfully synthesized from clay sourced from Kono-Boue and Chokocho, Rivers state, Nigeria after alkaline treatment of its metakaolin. This work demonstrated the development of hydrothermal process to produce an important industrial catalyst (zeolite) from locally sourced catalyst. The X-ray diffraction analysis confirmed the presence of zeolitic mineral phases in both $\mathrm{KK}$ and CK crystallized samples respectively. However, the CK sample was more crystalline as shown by sharper intense XRD peaks, rougher surface on the SEM micrograph and sharper bands on the FT-IR. Both samples had similar bands especially the characteristic zeolitic O-H stretching at $3488 \mathrm{~cm}^{-1}$. The XRF showed the presence of higher silica to alumina ratios of 10.73 and 14.36 after treatments while the EDS showed the absence of some toxic metals implying that the synthesized zeolites were safe and environmentally friendly. The zeolites formed have shown that the hydrothermal modification of reactive kaolin into zeolite $\mathrm{X}$ depended solely on the ageing time, reaction temperature, metakaolinization temperature and $\mathrm{NaOH}$ concentration.

\section{Conflicts of Interest}

The authors declare no conflicts of interest regarding the publication of this paper.

\section{References}

[1] Adamis, Z. and Timar, M. (1980) Investigations of the Effects of Quartz, Aluminium Silicates and Colliery Dusts on Peritoneal Macrophages. In: Brown, R.C., Gormley, I.P., Chamberlain, M. and Davies, R., Eds., The in Vitro Effects of Mineral Dusts, Academic Press, London, 13-18. 
[2] Breck, W. (1974) Zeolite Molecular Sieves: Structure, Chemistry, and Use. New York, 25.

[3] Olaremu, A., Odebunmi, E. and Nwosu, F. (2018) Synthesis of Zeolite from Kaolin Clay from Erusu Southwestern Nigeria. Journal of Chemistry Society of Nigeria, 43, 381-786.

[4] Adefila, S., Ajayi, A. and Atta, Y. (2007) Synthesis of Faujasite Zeolites from Kanakara Kaolin Clay. Journal of Applied Sciences Research, 3, 1017-1021.

[5] Ajayi, A. (2012) Development of Large Pore Zeolites from Kaolinite Clay. Doctoral Dissertation, Ahmadu Bello University, Zaria.

[6] Aderemi, B. (2004) Preliminary Studies on Synthesis of Zeolite from Local Clay. Nigerian Journal of Scientific Research, 4, 7-10.

[7] Edomwonyi-Otu, L.C., Aderemi, B.O., Edomwonyi-Otu, O., Simo, A. and Maaza, M. (2012) Alum Production from Some Nigerian Kaolinite Deposits. International Journal of Engineering Research in Africa, 7, 13-19. https://doi.org/10.4028/www.scientific.net/JERA.7.13

[8] Aroke, U., El-Nafaty, A. and Osha, O. (2013) Properties and Characterization of Kaolin Clay from Alkaleri, North-Eastern Nigeria. International Journal of Emerging Technology and Advanced Engineering, 3, 2250-2459.

[9] Konne, J., Gbarakoro, S. and Boisa, N. (2016) Characterization of Kono-Boue as Possible Catalyst for Biodiesel Production. International Journal of science and Research, 5, 924-928. https://doi.org/10.21275/v5i6.NOV164059

[10] Ezekiel, O., Adekunle, G., Friday, N. and Adedapo, A. (2018) Synthesis of Zeolite from Kaolin Clay from ErusuAkoko Southwestern Nigeria. Journal of Chemical Society of Nigeria, 43, 381-786.

[11] Mgbemere, H., Lawal, G., Ekpe, C. and Chaudhary, A. (2018) Synthesis of Zeolite-A Using Kaolin Samples from Darazo, Bauchi State and Ajebo Ogun State in Nigeria. Nigerian Journal of Technology, 37, 87-95. https://doi.org/10.4314/njt.v37i1.12

[12] Bai, H.-X., Zhou, L.-M., Chang, Z.-B., Zhang, C. and Chu, M. (2018) Synthesis of Na-X Zeolite from Longkou Oil Shale Ash by Alkaline Fusion Hydrothermal Method. Carbon Resources Conversion, 1, 245-250. https://doi.org/10.1016/j.crcon.2018.08.005

[13] Isernia, L.F. (2013) FTIR Study of the Relation between Extra-Framework Aluminium Species and the Adsorbed Molecular Water, and its Effect on the Acidity in ZSM-5 Steamed Zeolite. Materials Research, 16, 792-802. https://doi.org/10.1590/S1516-14392013005000044

[14] Emofuriefa, W., Kayode, A. and Coker, S. (1992) Mineralogy, Geochemistry and Economic Evaluation of the Kaolin Deposits Ubulu-Uku Awo-Omama and Buan in Southern Nigeria. Journal of Mining and Geology, 28, 211-220.

[15] King, D., Cooper, D. and Sanderson, M. (1991) Preparation of Catalysts. Elsevier, Amsterdam, 247.

[16] Belviso, C., Cavalcante, F., Lettino, A. and Fiore, S. (2013) A and X-Type Zeolites Synthesized from Kaolinite at Low Temperature. Applied Clay Science, 80-81, 162-168. https://doi.org/10.1016/j.clay.2013.02.003

[17] Król, M., Mozgawa, W., Jastrzębski, W. and Barczyk, K. (2012) Application of IR Spectra in the Studies of Zeolites from D4R and D6R Structural Groups. Microporous and Mesoporous Materials, 156, 181-188. https://doi.org/10.1016/j.micromeso.2012.02.040

[18] Akolekar, D., Chaffee, A. and Howe, R.F. (1997) The Transformation of Kaolin to Low-Silica X Zeolite. Zeolites, 19, 359-365.

https://doi.org/10.1016/S0144-2449(97)00132-2 